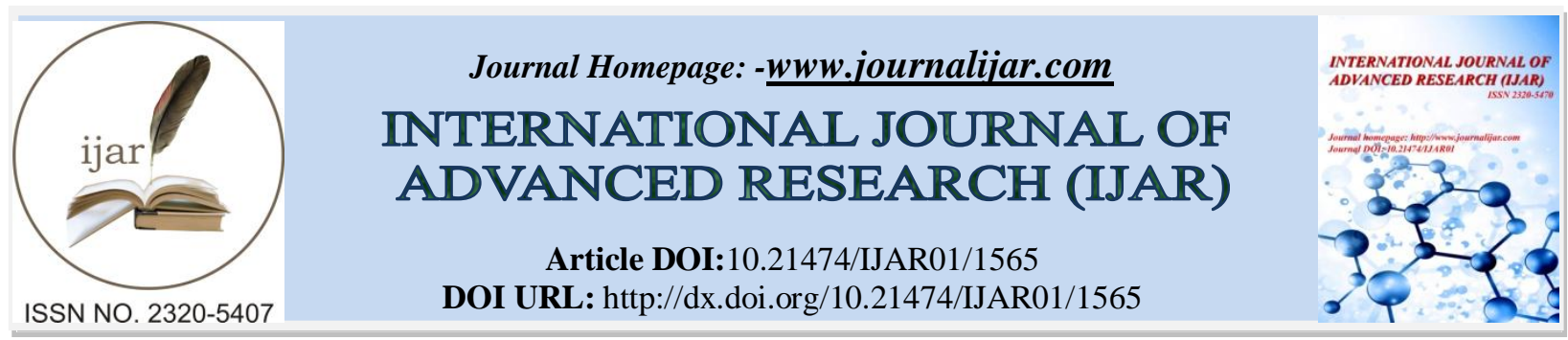

RESEARCH ARTICLE

\title{
EVALUATION OF OXIDATIVE STRESS AND REPRODUCTIVE POTENTIAL IN FEMALE RATTUS RATTUS, BANDICOTA BENGALENSIS AND TATERA INDICA RATS.
}

Shasta Kalra* and Gurinder Kaur Sangha.

Department of Zoology, Punjab Agricultural University, Ludhiana-141004, India.

\section{Manuscript Info}

Manuscript History

Received: 15 July 2016

Final Accepted: 26 August 2016

Published: September 2016

Key words:-

Antioxidants, Oxidative stress,

Environmental contaminants, Proteins.

\section{Abstract}

The Malwa region of Punjab, India, is facing an unprecedented crisis of environmental health linked to indiscriminate, excessive, and unsafe use of pesticides, fertilizers, and poor groundwater quality. The present study was envisaged to investigate the possible effect of environmental contaminants on the reproductive outcome in female Rattus rattus, Bandicota bengalensis and Tatera indica inhabiting South-West region of Punjab in North India. A significant difference in organ weights between Bathinda rats and control rats was observed. Levels of total proteins were found to be decreasein all the rats collected from Bathinda region. Activity levels of OS parameters namely catalase (CAT), superoxide dismutase (SOD), glutathione transferase (GST), glutathione reductase (GR) and glutathione peroxidise (GPx) were differentially alteredand the products of oxidation namely, malondialdehyde increased significantly $(\mathrm{p}<0.05)$ in rats collected from Bathinda district as compared to control rats. Histomorphological studies of ovary revealed increased follicular atresia in rats of Malwa region. The results obtained indicate that environmental contaminants for prolonged period might be responsible for altering antioxidant defence system and inducing oxidative stress in rats inhabiting south- west region of Punjab.

Copy Right, IJAR, 2016,. All rights reserved.

\section{Introduction:-}

Agriculture is the major occupation of the South Western people of Punjab (Thakur et al., 2008). Cotton is a major crop in this region, which requires excessive use of pesticides to control the infestation of pests, as the pests have developed resistance to the pesticides (Shetty 2004). Cotton cultivation implies high use of a dangerous cocktail of pesticides- Organochlorines (Aldrin, Heptachlor), Carbmates (Aldicarb), Organophosphates (Chloropyriphos, Acephate, Ethion, Triazophos) and Synthetic pyrethyroids (Fenvelrate, Alphametharin, Cypermethrin) (Singh and Kaur, 2012).

The farmers and primarily agricultural workers are inadvertently exposed to pesticides through occupational use at all stages starting from pesticide purchase, transport, storage, dilution of pesticide concentrate, leaking of spray equipment, and inhalation during pesticide spraying (Maroni et al., 2000). Irrational use of pesticides intended for managed agricultural and other domestic practices has now become the concern to the public health regulatory authorities, as it not only produces adverse biological effects against the target species but also have the potential to 
affect the health of non-target species (Abdollahiet al.,2004), through the production of reactive oxygen species (ROS). OS occurs when production of ROS overrides antioxidant capacity in target cells, resulting in the damage of macromolecules such as nucleic acids, lipids and proteins (Agrawal and Sharma,2010).

Pesticides, though present in the environment in small quantities as compared to other contaminants such as industrial wastes and fertilizers may causes reproductive toxicity through direct damage to cells, interference with biochemical processes necessary for normal cell function and biotransformation resulting in toxic metabolites (Hasmi and Khan, 2011;Mathur and Cynthia, 2006).

Earlier studies give some indication of increased reproductive risks of exposure to pesticide/heavy metals, but the epidemiological evidences do not allow any clear inference to be drawn (Thakur et al.,2010; Singh et al.,2012). So in present investigation, the toxicity effects of environmental contaminants were carried out in terms of oxidative stress biomarkers in ovaries of femaleRattusrattus, B.bengalensisand T.indica rats inhabiting South-West region of Punjab in North India.

\section{Material and Methods:-}

\section{Chemicals:-}

All chemicals were purchased from Sigma-Aldrich, SDFCL (SD Fine-Chem Ltd), SRL (Sissco Research Laboratories Pvt. Ltd). All chemical used were either of analytical grade or the highest purity commercially available.

\section{Animals:-}

Female field rats Rattusrattus, BandicotabengalensisandTateraindica were trapped from fields of Bathinda district of South West region of Punjab. Same species of rats were also collected from PAU, Ludhiana and adjoining areas and they served as control rats. All methods and procedures of animal handling during research were conducted in accordance with the guidelines of Committee for the Purpose of Control and Supervision of Experiments on Animals (CPCSEA), India and experiments conducted in the present study were duly approved by Institutional Animal Ethics Committee (IAEC), Guru AngadDev Veterinary and Animal Sciences University, Ludhiana vide letter no 3901-35 dated 06-08-2012.

\section{Experimental design:-}

Animals were brought to laboratory, separated according to species and observed for morphological symptoms.

\section{Organ weight and Organosomatic Index:-}

After dissection reproductive organs viz: ovaries, oviduct and uterus were excised, cleared off the adhering tissue and weighed.The organo-somatic index (OSI) was calculated by using the following formula as per Chattopadhyayet al. (2011).

$$
\text { Organo }- \text { somaticIndex }(\text { OSI })=\frac{\text { Organweight }(g)}{\text { Livebodyweight }(g)} X 100
$$

\section{Biochemical studies:-}

For biochemical studies, ovary was homogenized in $2 \mathrm{ml}$ of phosphate buffer saline (PBS 0.1M, pH 7.4) and the homogenate was centrifuged at 3000 for r.p.m. for 10 min. Supernatant was used for estimation of total proteins by method of Lowry et al.(1951), CAT (catalase) by Aebi (1983), SOD (Superoxide Dismutase) by Marklund and Marklund(1974), GST (glutathione-S-transferase) by Habiget al. (1974), GR (glutathione reductase) by Carlberg and Mannervik (1985), GPx (glutathione peroxidase) by Hafemanet al. (1984), LPO (Lipid peroxidation) by Stocks and Dormandy (1971). Differentially modified levels of all biochemical parameters in control rats and rats collected from Bathinda region were assessed for their correlation with oxidative stress.

\section{Histological studies:-}

Ovaries were placed in alcoholic Bouin's fixative for 24 hours and then dehydrated in graded series of alcohols, cleared in benzene and embedded in paraffin wax (melting point $58-60^{\circ} \mathrm{C}$ ). The $5 \mu \mathrm{m}$ thick sections were cut using microtome and stained with haematoxylin and eosin by routine procedures and slides were observed under OLYMPUS CH20i microscope and photographed to study morphological characteristics of normal follicle, atretic follicle and corpora lutea were examined in ovary. 
The follicles in each section of ovary were categorized into the following groups:

Stage I : Primary follicles with 1-2 layers of granulosa cells surrounding the oocyte.

Stage II : Secondary follicles with 2-4 complete layers of granulosa cells around ovum.

Stage III : Tertiary follicles with 4-6 or more layers of granulosa cells.

Stage IV : Early antral follicles with small patches of antrum in granulosa cells andantral cavity still not completely formed.

Stage V : Mature follicles having fully formed antral cavities with antral fluid; cumulus oophorous clearly demarcated from rest of granulosa cells by stalk of cells.

The stage of corpora lutea was also determined. The number of follicles recorded in each stage represented absolute number of follicles per ovary. The results expressed as mean number of follicles \pm S.E. in each stage per ovary and averages were based on ovaries from different animals forming a sub-group. Thus the total number of follicles in 5 stages was counted in ovaries of all rats.

Atretic follicles were distinguished from normal follicles either by the presence of pyknotic bodies or by the disruption or disintegration of granulosa cell layers, uneven thickness of granulosa cells and invasion of oocyte by granulosa cells.

The percentage of atresia was calculated as follows:

$\frac{\text { Number of atretic follicle in a stage }}{\text { Number of atretic }+ \text { healthy follicles of a stage }} \times 100$

\section{Statistical analysis:-}

All statistical comparisons for organ weight and biochemical analysis were presented as the mean \pm standard error of mean (S.E.M). Comparisons were made between control and Bathinda rats belonging to different species on computer using t-test. A "P" value of 0.05 was selected as a criterion for statistically significant differences.

\section{Result and Discussion:- Organ weight:-}

All the rats collected from Malwa region did not show any significant changes in reproductive organs weight as compared to control female rats (Table 1). The weight of ovaries and oviduct was comparable in control rats and rats collected from the study area. Significant decrease in uterus weight of Bandicotabengalensisand Tateraindicarats collected from Malwa region (Table 1).

\section{Biochemical observations:-}

The total protein contents were found to be non-significantly lower in ovaries of Tateraindicarats while it decreased significantly in ovaries of Rattusrattusand Bandicotabengalensisrats collected from Malwaregion as compared to control rats (Table 2).

Catalase activity and glutathione peroxidase levels decreased non significantly in ovaries of both the species of rats of study area as compared to the control group $(\mathrm{P}<0.05)$. Slight increase in the activity of SOD, GPxand GR was observed in rats of Malwa region. Pesticide contamination in the Malwa region caused significant increase in the MDA levels as a result of lipid peroxidation (LPO) (Table 2).

\section{Histological Studies in ovary:-}

The follicular kinetics in serial sections of the ovaries of control and those collected from Bathinda were studied under the light microscope and the follicles were categorized under five groups i.e. primary, secondary, tertiary, early antral and antral follicles as suggested by Pederson (1970). It was observed that the number of normal follicles in all the stages of follicles was higher in control Rattusrattus,Bandicotabengalensisand Tateraindica and their number decreased in the ovaries of rats collected from Bathinda region (Table 6-8). Along with the normal follicles of all the five types, the number of atretic follicles of all the categories was also counted and it was observed that number of atretic follicles of primary, secondary and tertiary stages was comparable in control and Bathinda rats. In 
Bandicotabengalensis, the percent artesia was observed to be $26.31 \%$ in control rats in contrast to $29.09 \%$ in rats collected from Bathinda. The artesia was observed to be $25.00 \%$ and $30.64 \%$ in control rats and Bathinda rats of Tateraindica respectively (Table 3-5).The number of primordial, primary, preantral and small antral follicles was non-significantly reduced in both the species of rats collected from Bathinda region (Table 3-5)

Histomorphological studies of ovary also revealed increased follicular atresia in all the species of rats collected fromMalwa region (Plate1).

Table 1:- Relative mass of reproductive organs (g/100 g bw) in different species of female rats

\begin{tabular}{|l|l|l|l|l|l|l|}
\hline & \multicolumn{2}{|c}{ Rattusrattus } & \multicolumn{2}{l|}{ Bandicotabengalensis } & \multicolumn{2}{l|}{ Tateraindica } \\
\hline Organs & Control & Bathinda & Control & Bathinda & Control & Bathinda \\
\hline Ovary & $0.015 \pm 0.00$ & $0.015 \pm 0.00$ & $0.009 \pm 0.01$ & $0.009 \pm 0.00$ & $0.008 \pm 0.00$ & $0.008+0.00$ \\
\hline Oviduct & $0.008 \pm 0.01$ & $0.008 \pm 0.01$ & $0.002 \pm 0.01$ & $0.002 \pm 0.01$ & $0.008 \pm 0.00$ & $0.008+0.00$ \\
\hline Uterus & $0.032 \pm 0.00$ & $0.032 \pm 0.00$ & $0.030 \pm 0.04$ & $0.022 \pm 0.01^{*}$ & $0.025 \pm 0.00$ & $0.020 \pm 0.00^{*}$ \\
\hline
\end{tabular}

Values are Mean $\pm \mathrm{SE}$

Table 2:-Ovary enzymatic antioxidant parameters ( $\mathrm{mg} \mathrm{g}^{-1}$ wet weight of tissue) of Bandicotabengalensis and Tateraindicafemale rats.

\begin{tabular}{|l|c|c|c|c|c|c|}
\hline & \multicolumn{2}{|c|}{ Rattusrattus } & \multicolumn{2}{l|}{ Bandicotabengalensis } & \multicolumn{2}{c|}{ Tateraindica } \\
\hline Parameters & Control & Bathinda & Control & Bathinda & Control & Bathinda \\
\hline Protein & $5.06+0.77$ & $4.78+1.04^{*}$ & $5.05+0.68$ & $4.08+0.34^{*}$ & $4.44 \pm 0.30$ & $4.38+0.33$ \\
\hline CAT & $36.70 \pm 3.19$ & $32.79 \pm 7.71^{*}$ & $31.12 \pm 0.25$ & $30.65 \pm 3.58$ & $39.11 \pm 3.95$ & $39.10 \pm 7.92$ \\
\hline SOD & $13.53 \pm 0.26$ & $14.43 \pm 1.37$ & $8.34 \pm 0.41$ & $9.45 \pm 0.29$ & $11.00 \pm 01.49$ & $11.64 \pm 1.18$ \\
\hline GST & $0.45 \pm 0.02$ & $0.44 \pm 0.02$ & $0.45 \pm 0.01$ & $0.46 \pm 0.004$ & $0.45 \pm 0.23$ & $0.47 \pm 0.01$ \\
\hline GR & $0.07 \pm 0.01$ & $0.08 \pm 0.01$ & $0.06 \pm 0.01$ & $0.09 \pm 0.01$ & $0.07 \pm 0.05$ & $0.09 \pm 0.01$ \\
\hline GPx & $0.21 \pm 0.01$ & $0.16 \pm 0.01$ & $0.16 \pm 0.03$ & $0.12 \pm 0.26$ & $0.19 \pm 0.05$ & $0.17 \pm 0.08$ \\
\hline LPO & $8.13 \pm 0.17$ & $10.44 \pm 0.18$ & $7.53 \pm 0.2$ & $8.51 \pm 0.24$ & $8.13 \pm 0.17$ & $8.48 \pm 0.13$ \\
\hline
\end{tabular}

All the values are Mean \pm SE of 5 animals in each group,

*Statistically significant different $(\mathrm{p} \leq 0.05)$ as compared to control

Units: Proteins (mg/g tissue), GPx (U/mg protein), SOD (U/mg protein), CAT ( $\mu$ mole of $\mathrm{H}_{2} \mathrm{O}_{2}$ decomposed $/ \mathrm{min} / \mathrm{mg}$ protein), GR ( $\mu$ moles of NADPH conjugate/ $\mathrm{min} / \mathrm{mg}$ protein), GST ( $\mu$ moles of GSH-CDNB conjugate formed/ $\mathrm{min} / \mathrm{mg}$ protein), LPO (nM MDA/100 mg tissue).

Table 3:-Percentage of atresia in ovaries of control and Bathinda rats in Rattusrattus.

\begin{tabular}{|l|c|c|c|c|}
\hline Treatment & $\begin{array}{c}\text { Total number } \\
\text { of normal follicles }\end{array}$ & $\begin{array}{c}\text { Total number of } \\
\text { atretic follicles }\end{array}$ & $\begin{array}{c}\text { Total number } \\
\text { of follicles }\end{array}$ & \% Atresia \\
\hline Control & 46 & 18 & 64 & $28.12 \%$ \\
\hline Bathinda & 40 & 16 & 56 & $28.57 \%$ \\
\hline
\end{tabular}

Values are Mean \pm SE

Table 4:-Percentage of atresia in ovaries of control and Bathinda rats in Bandicotabengalensis.

\begin{tabular}{|l|c|c|c|c|}
\hline Treatment & $\begin{array}{c}\text { Total number } \\
\text { of normal follicles }\end{array}$ & $\begin{array}{c}\text { Total number of } \\
\text { atretic follicles }\end{array}$ & $\begin{array}{c}\text { Total number } \\
\text { of follicles }\end{array}$ & \% Atresia \\
\hline Control & 42 & 15 & 57 & $26.31 \%$ \\
\hline Bathinda & 39 & 16 & 55 & $29.09 \%$ \\
\hline
\end{tabular}

Values are Mean \pm SE

Table 5:-Percentage of atresia in ovaries of control and Bathinda rats in Tateraindica.

\begin{tabular}{|l|c|c|c|c|}
\hline Treatment & $\begin{array}{c}\text { Total number } \\
\text { of normal follicles }\end{array}$ & $\begin{array}{c}\text { Total number of } \\
\text { atretic follicles }\end{array}$ & $\begin{array}{c}\text { Total number } \\
\text { of follicles }\end{array}$ & \% Atresia \\
\hline Control & 48 & 16 & 64 & $25.00 \%$ \\
\hline Bathinda & 43 & 19 & 62 & $30.64 \%$ \\
\hline
\end{tabular}

Values are Mean \pm SE 
Table 6:-Follicular kinetics in the ovaries of control and Bathinda rats in Rattusrattus.

\begin{tabular}{|c|c|c|c|c|c|c|c|c|c|c|}
\hline \multirow{2}{*}{$\begin{array}{l}\text { Treatm } \\
\text { ent }\end{array}$} & \multicolumn{2}{|c|}{$\begin{array}{l}\text { Number of primary } \\
\text { follicles }\end{array}$} & \multicolumn{2}{|c|}{$\begin{array}{l}\text { Number of } \\
\text { secondary follicles }\end{array}$} & \multicolumn{2}{|c|}{$\begin{array}{l}\text { Number of tertiary } \\
\text { follicles }\end{array}$} & \multicolumn{2}{|c|}{$\begin{array}{l}\text { Number of early } \\
\text { antral follicles }\end{array}$} & \multicolumn{2}{|c|}{$\begin{array}{l}\text { Number of antral } \\
\text { follicles }\end{array}$} \\
\hline & Normal & Atretic & Normal & Atretic & Normal & Atretic & $\begin{array}{l}\text { Norma } \\
\text { l }\end{array}$ & Atretic & $\begin{array}{l}\text { Norma } \\
\text { l }\end{array}$ & Atretic \\
\hline $\mathrm{Co}$ & $\begin{array}{l}.00 \pm \\
2\end{array}$ & D. & $\begin{array}{l}11.00 \pm 0 . \\
44\end{array}$ & $\begin{array}{l}3.00 \pm 0 . \\
22\end{array}$ & $\begin{array}{l}11.00 \pm 0 . \\
21\end{array}$ & 26 & $\begin{array}{l}7.00 \pm 0 . \\
28\end{array}$ & $\begin{array}{l}3.00 \pm 0 \\
54\end{array}$ & $\begin{array}{l}8.00 \pm 0 . \\
27\end{array}$ & $\begin{array}{l}4.00 \pm 0 . \\
31\end{array}$ \\
\hline $\begin{array}{l}\text { Bathind } \\
\text { a }\end{array}$ & $\begin{array}{l}10.00 \pm 0 . \\
26\end{array}$ & $\begin{array}{l}3.00 \pm 0 . \\
25\end{array}$ & $\begin{array}{l}10.00 \pm 0 . \\
45\end{array}$ & $\begin{array}{l}3.00 \pm 0 . \\
21\end{array}$ & $\begin{array}{l}8.00 \pm 0.4 \\
3 \\
\end{array}$ & $\begin{array}{l}3.00 \pm 0 . \\
13\end{array}$ & $\begin{array}{l}5.00 \pm 0 . \\
21\end{array}$ & $\begin{array}{l}4.00 \pm 0 . \\
11\end{array}$ & $\begin{array}{l}6.00 \pm 0 . \\
21\end{array}$ & $\begin{array}{l}3.00 \pm 0 . \\
23\end{array}$ \\
\hline
\end{tabular}

Values are Mean \pm SE

Table 7:-Follicular kinetics in the ovaries of control and Bathinda rats in Bandicotabengalensis

\begin{tabular}{|c|c|c|c|c|c|c|c|c|c|c|}
\hline \multirow{2}{*}{$\begin{array}{l}\text { Treatm } \\
\text { ent }\end{array}$} & \multicolumn{2}{|c|}{$\begin{array}{l}\text { Number of primary } \\
\text { follicles }\end{array}$} & \multicolumn{2}{|c|}{$\begin{array}{l}\text { Number of } \\
\text { secondary follicles }\end{array}$} & \multicolumn{2}{|c|}{$\begin{array}{l}\text { Number of tertiary } \\
\text { follicles }\end{array}$} & \multicolumn{2}{|c|}{$\begin{array}{l}\text { Number of early } \\
\text { antral follicles }\end{array}$} & \multicolumn{2}{|c|}{$\begin{array}{l}\text { Number of antral } \\
\text { follicles }\end{array}$} \\
\hline & Normal & Atretic & Normal & Atretic & Normal & Atretic & $\begin{array}{l}\text { Norma } \\
\text { l }\end{array}$ & Atretic & $\begin{array}{l}\text { Norma } \\
\text { l }\end{array}$ & Atretic \\
\hline $\mathrm{Cc}$ & $\begin{array}{l}4.00 \pm \\
23\end{array}$ & $\begin{array}{l}\text { J.0 } \\
32\end{array}$ & $\begin{array}{l}13.00 \pm 0 . \\
54\end{array}$ & $\begin{array}{l}3.00 \pm 0 . \\
23\end{array}$ & $\begin{array}{l}10.00 \pm 0 . \\
25\end{array}$ & $\begin{array}{l}3.00 \pm 0 . \\
32\end{array}$ & $\begin{array}{l}9.00 \pm 0 . \\
32\end{array}$ & $\begin{array}{l}3.00 \pm 0 . \\
53\end{array}$ & $\begin{array}{l}9.00 \pm 0 . \\
21\end{array}$ & $\begin{array}{l}6.00 \pm 0 . \\
32\end{array}$ \\
\hline $\begin{array}{l}\text { Bathind } \\
\text { a }\end{array}$ & $\begin{array}{l}13.00 \pm 0 . \\
24\end{array}$ & $\begin{array}{l}3.00 \pm 0 . \\
15\end{array}$ & $\begin{array}{l}11.00 \pm 0 . \\
25\end{array}$ & $\begin{array}{l}3.00 \pm 0 . \\
22\end{array}$ & $\begin{array}{l}10.00 \pm 0 . \\
32\end{array}$ & $\begin{array}{l}5.00 \pm 0 . \\
54\end{array}$ & $\begin{array}{l}9.00 \pm 0 . \\
21\end{array}$ & $\begin{array}{l}4.00 \pm 0 . \\
12\end{array}$ & $\begin{array}{l}7.00 \pm 0 . \\
23\end{array}$ & $\begin{array}{l}5.00 \pm 0 . \\
21\end{array}$ \\
\hline
\end{tabular}

Values are Mean \pm SE

Table 8:-Follicular kinetics in the ovaries of control and Bathinda rats in Tateraindica

\begin{tabular}{|c|c|c|c|c|c|c|c|c|c|c|}
\hline \multirow{2}{*}{$\begin{array}{l}\text { Treatm } \\
\text { ent }\end{array}$} & \multicolumn{2}{|c|}{$\begin{array}{l}\text { Number of primary } \\
\text { follicles }\end{array}$} & \multicolumn{2}{|c|}{$\begin{array}{l}\text { Number of } \\
\text { secondary follicles }\end{array}$} & \multicolumn{2}{|c|}{$\begin{array}{l}\text { Number of tertiary } \\
\text { follicles }\end{array}$} & \multicolumn{2}{|c|}{$\begin{array}{l}\text { Number of early } \\
\text { antral follicles }\end{array}$} & \multicolumn{2}{|c|}{$\begin{array}{l}\text { Number of antral } \\
\text { follicles }\end{array}$} \\
\hline & Normal & Atretic & Normal & Atretic & Normal & Atretic & $\begin{array}{l}\text { Norma } \\
1\end{array}$ & Atretic & $\begin{array}{l}\text { Norma } \\
\text { l }\end{array}$ & Atretic \\
\hline $\mathrm{Co}$ & $\begin{array}{l}12.00 \pm \\
0.13\end{array}$ & $\begin{array}{l}2.00 \pm 0 . \\
23\end{array}$ & 45 & $\begin{array}{l}4.00 \pm 0 . \\
52\end{array}$ & $\begin{array}{l}10.00 \pm 0 \\
11\end{array}$ & $\begin{array}{l}2.00 \pm 0 . \\
16\end{array}$ & $\begin{array}{l}8.00 \pm 0 . \\
23\end{array}$ & $\begin{array}{l}2.00 \pm 0 . \\
40\end{array}$ & $\begin{array}{l}8.00 \pm 0 . \\
21\end{array}$ & $\begin{array}{l}6.00 \pm 0 . \\
32\end{array}$ \\
\hline $\begin{array}{l}\text { Bathind } \\
\text { a }\end{array}$ & $\begin{array}{l}11.00 \pm 0 . \\
45\end{array}$ & $\begin{array}{l}3.00 \pm 0 . \\
11\end{array}$ & $\begin{array}{l}11.00 \pm 0 . \\
43\end{array}$ & $\begin{array}{l}3.00 \pm 0 . \\
11\end{array}$ & $\begin{array}{l}9.00 \pm 0.4 \\
2\end{array}$ & $\begin{array}{l}3.00 \pm 0 . \\
12\end{array}$ & $\begin{array}{l}7.00 \pm 0 . \\
11\end{array}$ & $\begin{array}{l}4.00 \pm 0 . \\
31\end{array}$ & $\begin{array}{l}7.00 \pm 0 . \\
25\end{array}$ & $\begin{array}{l}7.00 \pm 0 . \\
21\end{array}$ \\
\hline
\end{tabular}

Values are Mean \pm SE 

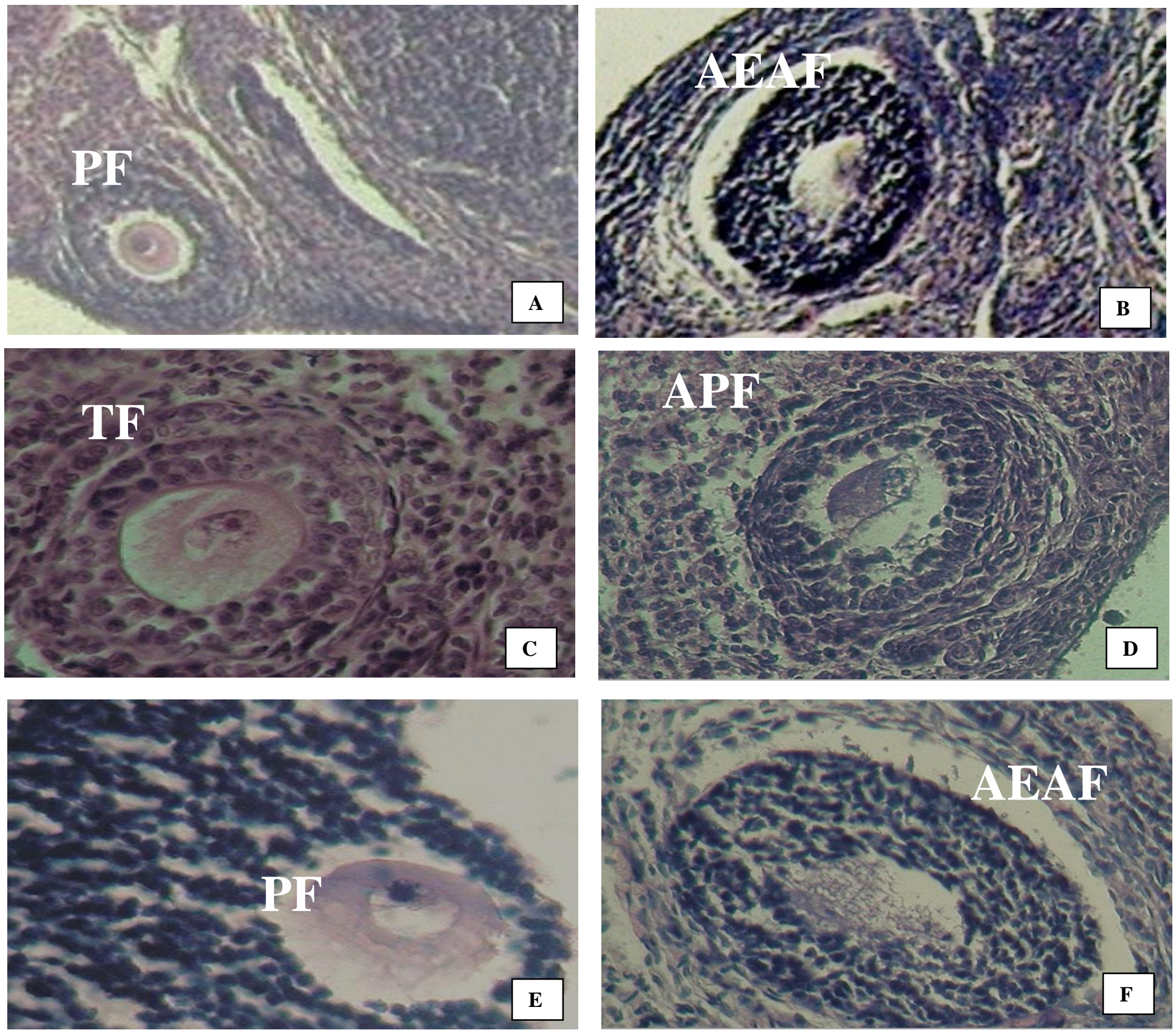

PLATE 1:-

Fig. A,C, E:-T.S. of ovary of a control femaleRattusrattus(Fig. A), Bandicotabengalensis(Fig. C)and Tateraindica(Fig. E) showing primary follicle (PF) and tertiary follicle (TF) (X 400).

Fig B:-T.S. of ovary of a femaleRattusrattuscollected from Bathinda district showing atretic early antral follicle (AEAF) (X 400).

Fig D:-T.S. of ovary of a femaleBandicotabengalensis collected from Bathinda district showing atreticprimary follicle (APF) (X 400)

Fig F:-T.S. of ovary of a femaleTateraindica collected from Bathinda district showing atretic early antral follicle (AEAF) (X 400). 


\section{Discussion:-}

Pesticides are widely used throughout the world especially in agriculture to protect crops, but relatively little is known about their possible adverse health effects, especially female reproductive effects. Nonsignificant changes in the weight of ovary and oviduct was observed in the present study while decreased uterus weight of rats of study area was comparable to a number of studies (Sanghaet al., 2013). The maintenance of high redox potential is a prerequisite for assuring the reproductive system functions in a healthy organism (Fujiiet al., 2005). Physiologically, ROS is increased in ovary after the preovulatory gonadotropin surge and also in corpus luteum (CL) during steroidogenesis, which involves the Cytochrme P450 system. However, the detoxification of ROS would particularly be important for oocyte maturation and embryo development (Fujiiet al., 2005). If free radicals are not neutralised by endogenous or exogenous antioxidant molecules such as SOD, then lipid peroxidation would occur at the cell membrane. In these cells, unsaturated lipids converted to peroxides would produce degradation products with toxic aldehyde moieties such as MDA. These subsequently interfere with the ovarian reproductive system (Yeneret al., 2013). Decreased CAT activity and increased SOD activity levels were observed in Bathinda rats during current investigation, which may be assumed to block the free radical load. Joint action of phoxim and methomyl has also been reported to induce reproductive toxicity through varied SOD activity. GST is the major phase II detoxification enzyme and plays an important role in the metabolism of xenobiotic substances, while reduced glutathione (GR) is a key cellular antioxidant that detoxifies ROS and is predominant intracellularily in nearly all animal cells (Sangha and Kalra, 2016; Kostaropoulos, 2001). The increased GST activity may probably be due to pesticide induced follicular loss and a sequestering mechanism of detoxification (Kostaropoulos, 2001). GST protein activity was also increased in ovary of female rats treated with the occupational chemical 4vinylcyclohexene diepoxide (VCD) as compared to control. Lower activity levels of GPx in the present studies were also in consent with the 4-vinylcyclohexene-treated female rats (Starlinet al.,2013). GPx activity levels were also lowered in ovary of female rats exposed to imidacloprid for 90 days (Kapoor et al., 2011). Decline in levels of GPx is considered to be an important factor for cancerous abnormality in the tissues (Starlinet al.,2013). The increase in the ovarian MDA in the present study may be possibly due to increased generation of ROS induced by TZ. The increased MDA observed in different tissues following an OPs exposure has been ascribed to the excessive production of ROS, which can lead to oxidative injuries of important cellular macromolecules such as lipids, proteins, and nucleic acids. An increased lipid peroxidation in ovary homogenate of imidaclopridtreated female rats has also been observed (Kapoor et al.,2011) and is in correlation with the present study. Güneyet al. (2007) also found that subchronic administration of methidathion pesticide to female rats caused ovarian damage through elevated lipid peroxidation.

The present study revealed a significant increase in the follicular atresia in the ovaries of all rats collected from Malwa district. Atresia was also found to be more in cypermethrin-treated rats compared to control (Sanghaet al., 2013).

\section{Conclusion:-}

In conclusion, it can be inferred that environmental contaminants may produce adverse reproductive effects, evidenced by the altered levels or activities of antioxidants such as CAT, GR, GPx, SOD and GST enzymes and lipid peroxidationandovary damage a fact that is further reaffirmed by the deranged histoarchitecture inRattusrattus, Bandicotabengalensisand Tateraindica inhabiting Bathinda district of South-west Punjab. Thus, it is speculated that environmental contaminants may be the reason of inducing oxidative and altering the antioxidant defense system in rats collected from Bathinda region.

\section{References:-}

1. Abdollahi, M. A. Ranjbar S., Shadnia S., NikfarA.and Rezaie (2004). Pesticides and oxidative stress: a review. Med. Sci. Monit., 10 (6): 141-147.

2. Aebi, H. (1983). Catalase In: Bergmeyer H U and Weinheim (ed) Methods of Enzymatic Analysis. Academic Press.Pp227-282.

3. Agarwal, A., and Sharma B. (2010). Pesticides induced oxidative stress in mammalian systems: Review article. Int J Biol Med Res 1:90-104.

4. Carlberg, I., and Mannervik B. (1985).Glutathione reductase. Methods. Enzymol.,113:484-490.

5. Chattopadhyay, S., Podder S., Agarwal S.and Bhattacharya S.(2011).Fluoride-induced histipathology and synthesis of stress protein in liver and kidney of mice. Ach.Toxicol.,85: 327-335. 
6. Fujii, J. Y., Iuchi F. and Okada. (2005). Fundamental roles of reactive oxygen species and protective mechanisms in the female reproductive system. Reprod. Biol. Endocrinol.,3: 43.

7. Güney. M., Demirin H., Oral B., OzgünerM., Bayhan. andAltuntasI. (2007). Ovarian toxicity in rats caused by methidathion and ameliorating effect of vitamins $\mathrm{E}$ and C.Hum. Exp. Toxicol., 26 (6): 491-498.

8. Habig, W.H., Pabst M.J. and Jakoby W.B. (1974). Glutathione S-transferases. The first enzymatic step in mercapturic acid formation. J. Biol. Chem., 246:7130-7139.

9. Hafeman, D.G., Sunde R. A. and Hoekstra W.G. (1984). Effect of dietary selenium erythrocyte and liver glutathione peroxidise in the rat. J.Nutr.,104:580-587.

10. Hashmi, I. and Khan A. D. (2011). Adverse health effects of pesticide exposure in agricultural and industrial workers of developing country In: Stoytcheva M (ed)Pesticides in the Modern World - Pests Control and Pesticides Exposure and Toxicity Assessment. pp. 155-78. InTech | ISBN: 9533074573.

11. Kapoor, U., SrivastavaM.K. and SrivastavaL.P. (2011). Toxicological impact of technical imidacloprid on ovarian morphology, hormones and antioxidant enzymes in female rats.Food Chem. Toxicol., 49: 3086-3089.

12. Kostaropoulos, A.I., Papadopoulos A. Metaxakis E. Boukouvala E. and Papadopoulou-Mourkidou. (2001).Glutathione S-transferase in the defense against pyrethroids in insects.Insect Biochem. Mol. Biol.,31: 313-319.

13. Lowry, O. H., Rosebrough N. J., Farr A. L. and Randall A. J. (1951). Protein measurement with folin phenol reagent. J. Biol. Chem.,193:265-275.

14. Marklund, S. andMarklund G. (1974). Involvement of the superoxide anion radical in the autoxidation of pyrogallol and a convenient assay for superoxide dismutase. Euro. J.Biochem.47:469-474.

15. Mathur, P. P. and Cynthia, D'Cruz. (2011).The effect of environmental contaminants on testicular function. Asian J.Androl.,13: 585-591.

16. Maroni, M., Colosio C., Ferioli A. and Fait A. (2000). Toxicology: review. Toxicol.,143:5-91.

17. Mostafalou, S. and Abdollahi M. (2012). Current Concerns on Genotoxicity of Pesticides. Inter. J.Pharma.,8: 473-74.

18. Sangha, G. K and Kalra S. (2016). Evaluation of oxidative stress in rats (Rattusrattus) inhabiting Bathinda region of Punjab, India. Indian J. Anim. Res.50(2): 168-174.

19. Sangha, G.K., KaurK. andKheraK.S. (2013). Cypermethrin induced pathological and biochemical changes in reproductive organs of female rats. J. Environ. Biol., 34:99-105.

20. Shetty. (2004).Socio-Ecological Implications of Pesticide Use in India. Economic and political weekly 39(49):5261-5267.

21. Singh, A. and Kaur, M. I. (2012). A health surveillance of pesticide sprayers in Talwandi Sabo area of Punjab, North-West India. J. Hum. Ecol.,37(2):133-137.

22. Singh, L., Choudhary S.K. and Singh P.K. (2012). Pesticide concentration in water and sedimentof River Ganga at selected sites in middle Ganga plain. Int. J. Environ. Sci.,3 (1):260-274.

23. Starlin, T.,SathiyanathanP., RajC.A., RagavendranP., VidyaB. and Sunitha.(2013). Chemomodulatory effects of Ichnocarpusfrutescens $\mathrm{R} . \quad \mathrm{Br}$ against 4-vinylcyclohexane induced ovarian cancer in swiss albino mice.J. Acute Dis.,2 (2): 151-155.

24. Stocks, J. and DormandyT.L. (1971). The autoxidation of human red cell lipids induced by hydrogen peroxide. British J.Haem.,20(1):95-111.

25. Thakur, J. S., Rao T. B., Rajwanshi A., Parwana H. K. and Kumar R. (2008).Epidemilogical study of high cancer among rural agricultural community of Punjab in northern India. Int. J. Environ. Res. Pub.Health.,5: 399-407.

26. Yener, N. A.,Sinanoglu O., Ilter E.,Celik A., Sezgin G. and Midi A. (2013). Effects ofSpirulina on cyclophosphamide-induced ovarian toxicity in rats: biochemical and histomorphometric evaluation of the ovary. Biochem. Res. Int. ArticleID 764262, doi:10.1155/2013/764262. 